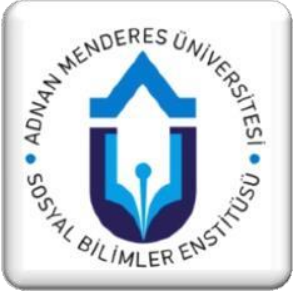

Makale Geçmiși

Başvuru Tarihi:30.04.2021

Kabul Tarihi:27.06.2021

\section{Turizm Rehberliğinde Kişisel Markalaşma $^{1}$}

Ragıp UÇAK ${ }^{2}$, Gül ERBAY ASLITÜRK ${ }^{3}$, Gülnur KARAKAŞ TANDOĞAN ${ }^{4}$

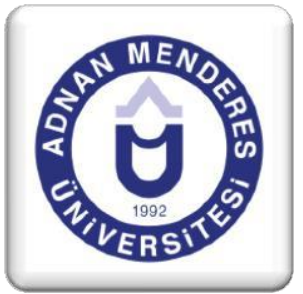

\author{
Article History \\ Date of Application:30.04.2021
}

Acceptance Date:27.06.2021

\title{
Özet
}

Turizm endüstrisinin mihenk taşlarından olan turist rehberleri, ziyaretçilerini destinasyonların çekici kısımlarına yönlendiren turizm profesyonelleridir. Ülkelerinin temsilcisi konumunda olan rehberler, bilgi veren, yol gösteren, liderlik eden ve ziyaretçilerin tatminini sağlayıp, olumlu deneyimler yaşamasına yardımcı olan kişilerdir. Diğer rehberlerden farklı olmak, ayırt edici birtakım özellikleri ön plana çıkartmak ve tercih edilen bir rehber olmak için kişisel marka kavramı bu alanda da kendisini göstermektedir. Hem turist rehberliği hem de kişisel markalaşma kavramı dijitalleşme ve rekabet koşulları gereği günümüzde giderek önemi arttırmaktadır. Birçok rolleri bulunan turist rehberleri, ülkelerinin önde gelen yüzlerindendir. Dolayısıyla, bu çalışmanın amacı turizm endüstrisinin ana karakterlerinden olan turist rehberlerinin kişisel marka süreçlerini incelemek, analiz etmek ve kişisel marka yaratmak isteyen rehber adaylarına yol göstermektir. Buradan hareketle, çalışmada kişisel marka haline gelmiş turist rehberleri ile nitel araştırma yöntemlerinden yarı yapılandırılmış görüşme tekniği ile veri toplanmıştır. Çalışma sonucunda rehberlikte markalaşmanın uygun olduğu saptanmıştır. Literatür ve çalışmaya katılan rehberlerden elde edilen verilerin 1şı̆̆ında rehberlikte markalaşmak oldukça yararlıdır. Rehberlik ve kişisel marka literatürünün liderlik, anlatım becerileri, görünürlük, süreklilik açılarından birbiriyle uyumlu olduğu görülmüştür. Görüşmeler sonucunda rehberlikte markalaşmak isteyen rehberlere çeşitli öneriler ve yol haritası çıkartılmıştır.

Anahtar Kelimeler: Turist Rehberi, Markalaşma, Kişisel Marka

\section{Personal Branding In Tourism Guidance}

\begin{abstract}
Tourist guides, one of the cornerstones of the tourism industry, are tourism professionals who guide their visitors to the attractive parts of the destinations. Guides, who are representatives of their countries, are people who provide information, guide, lead, and help visitors to have positive experiences by satisfying them. In order to be different from other guides, to highlight some distinctive features and to be a preferred guide, the concept of personal brand manifests itself in this field. Both tourist guiding and personal branding are increasingly important today due to digitalization and competition conditions. Tourist guides with many roles are among the leading faces of their countries. Therefore, the purpose of this study is to examine and analyze the personal branding processes of tourist guides, one of the main characters of the tourism industry, and to guide candidates who want to create a personal brand. Based on this, in the study, data were collected with the tourist guides who have become personal brands and the semi-structured interview technique, one of qualitative research methods. As a result of the study, it was determined that branding in guidance was appropriate. Branding in guidance is very useful in the light of the data obtained from the literature and guides participating in the study. Guidance and personal branding literature was found to be compatible with each other in terms of leadership, expressive skills,
\end{abstract}

\footnotetext{
${ }^{1}$ Bu çalışma Aydın Adnan Menderes Üniversitesi, Sosyal Bilimler Enstitüsü bünyesinde 2019 - 2020 eğitim öğretim yllında tamamlanan yüksek lisans tezinden üretilmiştir.

2 Doktora Öğrencisi, Aydın Adnan Menderes Üniversitesi, Sosyal Bilimler Enstitüsü, Turizm İşletmeciliği ABD, ragipucak95@gmail.com, ORCID: 0000-0002-4880-2403.

3 Doç. Dr., Aydın Adnan Menderes Üniversitesi, Turizm Fakültesi, Turizm Rehberliği Bölümü, gerbay@adu.edu.tr, ORCID: 0000-0003-4745-0116.

${ }^{4}$ Dr. Öğr. Üyesi, Aydın Adnan Menderes Üniversitesi, Turizm Fakültesi, Turizm İşletmeciliği Bölümü, gulnur.tandogan@adu.edu.tr, ORCID: 0000-0002-1283-3910.
} 
visibility and continuity. As a result of the interviews, various suggestions and a road map were prepared for guides who wanted to become a brand in guidance.

Keywords: Tour Guides, Branding, Personal Branding.

\section{Giriş}

Dünya üzerinde üretim ve tüketim gün geçtikçe artmaktadır. Nüfus artışıla paralel olarak tüketimin artması üretilen ürün ve hizmet çeşitliliğini de etkisi altına almaktadır. Her ürün ve hizmetin gündeme uygun olarak yenilik göstermesi gerekmektedir. Bu açıdan pazarlama araçlarını doğru bir şekilde üretime entegre etmek önemlidir. Marka, her bir ürünün tüketiciye tanıtılma şekillerini temsil etmektedir. Markaların tüketici algısındaki yeri, tüketim ve üretimin miktarını belirleyici kılmaktadır. Bir marka, ürünün kimliğini yansıtmakla beraber devamlılık göstermesi açısından kalıcılığını tüketime de yayması gerekmektedir. Bu doğrultuda üreticilerin markalama konusunda iyi bir gözlemci olması ve tüketim tarzlarını takip etmesi gerekmektedir. Son yıllarda ürün ve hizmet markalamasına yeni bir trend eklenmiştir.

Kişisel markalaşma olarak adlandırılan bu markalaşmada ürün, bireyin kendisidir. Kişisel olarak iş gücünü sergileyen birey, ismiyle bir marka oluşturmaya çalışmaktadır. Bireysel çalışmalarda bireyin kendini tüketiciye lanse etmesi kurumsal hizmet departmanlarına nazaran daha avantajlı bir durumdur. Bir nevi birey kendini markasını yaratarak onu tüketiciye pazarlamaktadır. Bu aşamada kişisel marka olma yolunda gerçekleşmesi gereken pek çok gereklilik bulunmaktadır. Ürün ve hizmet markalamasından çok bireysel markalamanın dezavantajları da hali hazırda bulunmaktadır. Bireyin çalıştığ iş̧teki performansını ve iş gücünü tüketici kesimine aktarımında diğer rakiplerinden farklı olduğunu gösterebilmesi ve bunu onların zihninde olumlu bir alg1 olarak yaratması gerekmektedir. Yarattığı markanın ulaşılabilirliği de önem taşımaktadır. Kişinin kendi markasını destekleyecek reklam ve benzeri araçlardan yardım alarak markayı güçlendirmesi, markayı geniş kitlelere yayabilmek açısından doğru bir strateji olabilmektedir.

Turistlerin kültürleri, tarihleri, gelenek ve görenekleri gibi birçok ülke mirasını tanımasında ve öğrenmesinde aracılık sağlayan bu mesleğin eğitimi için giderek artan bir ilerleyiş söz konusudur. Ülkede turist rehberliği eğitimi veren üniversitelerin sayısı mesleğin bilinirliliğine paralel olarak artış göstermektedir. $\mathrm{Bu}$ mesleğin daha geniş alanlara yayılmasını sağlamak ve istihdam gücünü arttırmak ülke tanıtımı ve misyonu için önemli bir adım olarak görülmektedir. Ülkenin sahip olduğu unsurları uluslararasında yayılmasına öncülük eden bu meslek grubu gelecek yıllarda da yine aynı şekilde devam etmesi beklenmektedir. Günümüzde turist rehberliği farklı bir boyuta erişmiştir. Faaliyette bulunan rehberlerin sayısındaki artış bu meslek grubu arasında bir rekabet ortamına ön ayak olmuştur. Bu rekabet kişisel bir marka yaratım sürecini geliştirmiştir. Rehberler diğer meslektaşlarından kendilerini ayırt edici özellikleriyle ön plana çıkmaktadır. Faaliyette bulunan rehberlerin sayısındaki artış bu meslek grubu arasında bir rekabet ortamına ön ayak olmuştur. Bu rekabet kişisel bir marka yaratım sürecini geliştirmiştir.

Günümüz dünyası sürekli bir değişim halindedir. Hem dünyada hem de sektörde giderek rekabetin artması ve kişilerin kendilerini benzerlerinden ayırması bir zorunluluk haline gelmektedir. Hem turist rehberliği hem de kişisel markalaşma kavramı dijitalleşme ve rekabet koşulları gereği günümüzde giderek önemi arttırmaktadır. Dolayısıyla, bu çalışmanın amacı turizm endüstrisinin ana karakterlerinden olan turist rehberlerinin kişisel marka süreçlerini incelemek, analiz etmek ve kişisel marka yaratmak isteyen rehber adaylarına yol göstermektir. Çalışma üç ana bölümden oluşmaktadır. Birinci bölümde turizm rehberliği, ikinci bölümde kişisel markalaşma ile ilgili kuramsal çerçeve ve ilgili araştırmalar ele 
alınmaktadır. Çalışmanın üçüncü bölümünde ise kișisel marka haline gelmiș turist rehberleri ile yapılan görüşmeler sonucundaki bulgulara yer verilmiş ve rehber adaylarına markalaşma yolunda öneriler sunulmuştur.

\section{Turist Rehberliği}

Turist rehberleri, en genel anlamıyla turizm sektöründe çalışan ve turistlerini belli bir süre içerisinde seyahat turlarına çıkaran kişilerdir. Turist rehberleri, ziyaret ettikleri ülkeyi misafir olarak keşfetmek isteyen yerli ve yabancı gezginler, geldikleri günden itibaren onlarla temas halinde olan ülkelerin temsilcileridir. Ayrıca tur rehberi, tura rehberlik eden, turdan sorumlu olan veya doğrudan ve ayrıntılı deneyimini belirli bir destinasyona aktaran kişidir. (Köroğlu 2013: 92).

Turizm alanındaki en eski mesleklerden biri olan turizm rehberliği, ülkedeki doğal ve tarihi kaynakların verimli ve sürdürülebilir pazarlanması için çok önemlidir. Rehber, bilgi veren ve yönlendiren kişi olarak bilinmektedir. Buna ek olarak turist rehberliği, tur yapmak, seyahate gitmek, eğlenmek, yeni kültürlerle etkileşim kurmak aynı zamanda açık hava mekânları şeklinde pek çok avantaj sağlayan eğlenceli ve basit bir iş gibi görünse bile oldukça fazla engel ve zorluğu bulunan bir iştir (Batman vd., 2000: 24).

Bir başka tanıma göre turist rehberleri, ülkeleri ve ziyaretçileri arasında önemli bir bağlantı görevi görmektedir. Bu nedenle rehberler, ziyaret edilen ülke veya destinasyon hakkında ayrıntılı bilgi sunan bir öğretmen, turistleri bir ülkeye veya bölgeye davet eden bir büyükelçi, barışçıl bir turist ilişkisi geliştiren ve sürdüren bir ev sahibi ve zamanı iyi kullanan bir yönetici olarak tanımlanmaktadır (Ap ve Wong, 2001: 552).

Rehberler tanıttıkları bölgenin kültürel ve doğal mirasını seyahat programına bağlı kalarak aktarmaktadırlar. Buna ek olarak, yazılı belgelerde tanımlandığı ve tüketiciye satıldığ şekliyle yürütülen tur operatörünün veya seyahat acentesinin faaliyetlerini ve seyahat acentesi adına seyahat programını yöneten kişilerdir (Tokay, 2015: 4).

Turist rehberleri, eğitimci, bilgi veren, tercüman, lider, rol modeli, kültürel elçi, halka açık olmayan alanlara erişimin kolaylaştırıcısı, tur ve grup organizatörü ve tur şirketlerinin temsilcisi gibi amaçlara hizmet etmektedirler (Black ve Weiler, 2005: 26). Buna ek olarak bir turist rehberinin ana sorumluluğu, bilgiyi hem eğlenceli hem de kültürel olarak kabul edilebilir bir şekilde sunarken turistlerin deneyimini en zevkli hale getirmektir (Boyle ve Arnott, 2004: 75).

Turist rehberleri, ziyaretçilere hâkim oldukları dillerde elçilik, eğitmenlik, liderlik eden ve genellikle bir otorite aracılığıyla yetkilendirilen, tanınan bir destinasyonda çeşitli niteliklere sahip olan, bir alanın kültürel ve doğal mirasını aktaran kişilerdir.

\subsection{Turist Rehberliği Mesleğinin Özellikleri}

Zamanın ilerlemesi ve küreselleşmenin artmasıyla seyahatler önem kazanmaktadır. Turizm sektörü bu sebeple önemlidir. Sektörün her bölümüne önemli işler düşmektedir. Ülke temsilcileri konumunda bulunan turist rehberleri, ziyaretçiler ile kendi aralarında önemli bir bağ kurmaktadırlar (Güzel, 2007: 8). Turistler, turist rehberleri sayesinde ziyaret ettikleri ülke halkı hakkında fikir sahibi olmaktadırlar. Rehberlerin konuşmaları, yargıları, davranış ve tutumları, ülke bakımından fiilen bağlayıcı konumundadır. Bir turist rehberi teknik bilgisinin üstünlügü ile aktardıklarının doğruluğuna misafirlerine inandırabilmiş ise sosyal ve politik konulardaki aktardıkları için de önemli bir inandırıcılık temeli oluşturmaktadır. Dolayısıyla turist rehberleri ülkeler için pozitif ve negatif anlamda pek çok şey yapabilmektedir (Ahipaşaoğlu, 2006: 68). 
Rehberler ülkelerini yabancılara, ziyaretçilere kendi sahip oldukları karakterleriyle temsil ettikleri için turizm endüstrisinde oldukça önemli görev, katk1 ve yükümlülükleri bulunmaktadır. Rehberlik oldukça fazla bilgi ve çok yönlü bir eğitim gerektirmektedir. Rehberler, detaylı bilgileri ile birlikte iyi bir lider, sosyolog, psikolog ve kültür elçisi olmak zorundadırlar (Çimrin, 1995: 42).

Turist rehberleri pek çok kişiye göre heyecan verici yerleri sıkça ziyaret eden, kaliteli restoranlarda yemek yiyen, lüks otellerde hoş zaman harcayan ve bunlar için ödeme yapılan kişilerdir. Ancak rehberler bütün bu olanakları elde edebilmekte için çok çalışmalıdır. $\mathrm{Bu}$ nedenle, rehberlerin mesleklerini yerine getirmek için genellikle evlerinden ayrı olmaları da aile yaşamlarını olumsuz bir şekilde etkileyebilir (Karakaş, 2018: 17). Öte yandan, tur yönetimi seyahat endüstrisinde önemli bir yere sahip olduğu için, turist rehberliği pek çok kişi tarafindan doyurucu bir meslek olarak görülmektedir. Turist rehberliği insan odaklı bir faaliyet olarak görülmekle birlikte, grubun ihtiyaçlarını karşılamak açısından tur liderleri kadar sorumlulukları olmadığını vurgulamaktadır (Mancini, 2001: 22).

Rehberlik yalnızca bir meslek olarak görülmemelidir. Rehberler ilk olarak ülkeye gelen turistlerle temasa geçtiğinden, ülkenin imajını olumlu ya da olumsuz olarak göstermektedir. $\mathrm{Bu}$ nedenle turist rehberleri sadece kendileri için değil, ülkeleri için çok titiz olmalı ve anlatımlarına özel dikkat göstermelidir (Akbulut, 2006: 64).

Mesleğinin özü gereği iyi bir iletişimci, eğitsel ve teknik özelliklerle beraber başarılı bir rehber olmak zorundadırlar (Batman vd. 2000: 25). Bütün mesleklerde olduğu gibi, turist rehberliği mesleğinde de başarılı olmak kolay değildir. Birtakım turist rehberlerinin başarılarını tamamen dışa dönük, bilgi aktarımında oldukça iyi, diğerleri problemli ve sakin bir şekilde problem çözme becerilerinde ustalaşmışladır. Bazı seyahat acenteleri şarkı söyleyebilecek, fikra veya küçük şakalar yapabilecek ve grup için oyun oynayabilecek bir animasyon uzmanı görmek istemektedirler. $\mathrm{Bu}$ seyahat acenteleri için turist rehberin eğlendirme yeteneğine sahip olması önemlidir, ancak bu ana bir unsur değildir. Yine bazı seyahat acenteleri, turlarında kültürel değerleri iyi aktarabilen ve yüksek ifade becerilerine sahip rehberleri tercih etmektedir. Bu nedenle, seyahat acenteleri, turlarına elverişli rehber seçiminde rehberlerin niteliklerini, bilgi ve yeteneklerini dikkate almaktadırlar (Tetik, 2006: $52)$.

\subsection{Turist Rehberinde Olması Gereken Nitelikler}

Turist rehberleri, bir destinasyonun temsil edilmesinde ve turizm deneyiminin kalitesinin algılanmasında önemli rol oynamaktadırlar. Ayrıca rehberler, yerel toplum için ekonomik faydaların sağlanmasında da stratejik bir faktördür. Bu açıdan, bir turist rehberi, tura katılan bireylerin memnuniyetini sağlamak ve ülkeyi veya bölgeyi daha iyi tanıtmak için belirli niteliklere ve özelliklere sahip olmalıdır (Çınar, 2018: 9).

Rehberler tur esnasında baskı altında olmasına rağmen, görevini yerine getirirken rehber sabırlı ve dikkatli olmalıdır. Ayrıca, turist rehberi adil olmalı, eşlik eden turist grubunun davranışını övmeli, turistlerin beklentilerini karşılamalı, yıkıcı davranışlarla karşılaştığında sakin olmalı, ziyaretçileri teşvik etmeli, gruba liderlik etmeli ve esnek olmalıdır. Bunlara ek olarak bir rehber asla monoton olmamalı, daima bilgilerini güncellemelidir. Dolayısıyla rehberler yeniliğe açık, günceli takip eden ve bilgilerini sürekli diri tutan kişiler olmalıdır (Batman vd. 2000: 24).

Turist rehberleri çeşitli niteliklere sahip olmalıdır. Grubun kontrolünün kaybedilmemesi, soğukkanlılık, adil olma, esnek davranma, mizahi anlayış, iyi bir hikâye anlatıcısı ve diplomatik niteliklerde profesyonel olarak gruba liderlik etmeleri gerekir. İşverenleri, 
müşterileri ve ülkelerinin turizm politikaları ile olan ilişkilerinden hareketlerinden sorumludurlar (Dahles, 2002: 786).

Rehberlik mesleğinin sorumluluklarını yerine getirmek ve misafirleri memnun etmek için her bir rolün bireysel olarak benimsenmesini gerektirdiğinden, turist rehberlerinin sahip olması gereken bazı nitelikleri bulunmaktadır (Tetik, 2006: 52). Bu nitelikler bilgi, yetenekler ve beceriler, kişilik özellikleridir.

Bilgi: Bir turist rehberinin sahip olması gereken en önemli niteliklerden biri, çeşitli konularda belirli miktarda bilgiye sahip olmaktır. Bu bilgiler; yabancı dil bilgisi, genel kültür bilgisi, diğer kültürler hakkında bilgi ve ilkyardım bilgisi şeklinde sıralanabilir.

Yetenekler ve Beceriler: Turist rehberlerinin, turistlerin ihtiyaçlarına cevap verebilmek ve beklentilerini karşılayabilmek için bazı temel beceri ve yeteneklerle donatılması gerekmektedir. Çeşitli becerilerin rehberler tarafından edinilmesi ve geliştirilebilmesi oldukça önemlidir. Bu beceriler; anlatım becerisi, iletişim becerisi, yorumlama becerisi, organizasyon ve koordinasyon becerisi, sorularla başa çıkabilme becerisi ve kendini yenileyebilme becerisidir (İrigüler, 2015: 18).

Kişilik Özellikleri: Turistler, ülkenin yanı sıra yerel halkın bir imajını oluşturmak için her şeyi gözlemler ve bu görüntü çoğunlukla turist rehberinden etkilenmektedir. Bilgi ve bazı becerilerin yanı sıra, turist rehberinin temsilini destekleyen ve tamamlayan bazı temel kişilik özellikleri ve fiziksel görünüm de vardır. Bunlar liderlik ruhu, dışa dönük ve misafirperver kişilik, mizah duygusu, iş ahlakı endişeleri ve fiziksel görünümdür (İrigüler, 2015: 23).

\section{Kişisel Marka Kavramı}

Marka, bir şirketin, kuruluşun veya bireyin onu deneyimleyen kişiler tarafindan algılanma şeklidir. Amerikan Pazarlama Birliği (AMA), bir markayı isim, terim, işaret, sembol veya tasarım veya bunların bir satıcı veya grup satıcısının mal ve hizmetlerini belirlemek ve diğer satıcılarınkinden ayırt etmek amacıyla bir birleşimi olarak tanımlamaktadır. Bu özellikler genellikle bir şirkete veya bireye özgüdür ve ürün ya da hizmetlerini rakiplerinden farklılaştırmayı amaçlamaktadır. Genel olarak marka, tüketicilerin inandığı bir sözdür. Şirketin yaptığı, söylediği ve sattığı her şey markayı etkiler, çünkü bunlar markanın güvenilirliğini artırmakta veya zayıflatmaktadır (Lukkarinen, 2019: 5).

Marka, bir ürüne veya işletmeye birtakım güven ve duygusal bağlılık hissi oluşturur ve daha yüksek kalite hissi yaratır. Markalaşmayı başarmak için işletmelerin kendine özgü özelliklerini, güçlü yönlerini kısa ve basit bir șekilde yürütmeleri gerekmektedir. Bir markanın var olup olmadığı değil; bir markanın ne kadar iyi yönetildiği önemlidir. Kalite, değer ve güvenilirliğe sahip, uygun şekilde oluş̧urulmuş bir marka, pazarlama işini azaltabilir ve uzun bir süre boyunca yüksek getiri ve kar marjları oluşturabilir (Charkas ve Eltun: 2014: 4).

Kişisel markalaşma ise, bireyin kendi içerisindeki benzersiz olanı anlamak, bunu farklılaşırmak ve kariyer kararlarına rehberlik etmesi için kullanmasıdır. Aynı zamanda bireyin gerçek kişiliğini ortaya çıkarması ve kişisel markayı sürekli ve devamlı olarak yaşamasıdır. Kişisel markalaşma, bir müşteriye değerli bir şey sunmak ve onu o müşteriyle duygusal bir bağ oluşturacak şekilde takdim etmektir (Zarkada, 2012: 3).

Kişisel markalaşma, bir kişinin becerilerini, benzersiz özelliklerini ve kişiliğini bir araya getiren bir süreçtir. Bunların bir araya gelmesiyle, birey anonim yüzler arasında görülme fırsatı veren güçlü bir kimlik haline gelmektedir. Bireyler itibar oluşturabilir ve güvenilirlik kurabilir, kendi alanlarındaki tanınırlıklarını artırabilir ve güven oluşturabilir. İnsanların bir 
bireyle ilişkilendirdiği değerler, eylemler ve yetenekler olumlu olmalı ve bireyin neyi temsil ettiğini göstermelidir. Kişisel bir marka, insanların bir birey algısını etkilemek ve bu algıyı firsata dönüştürmek için yaratılmış bir alternatif egodur. Kişinin ne yaptığını, kim olduğunu, neyi farklılaştırdığını ve kişinin hedef kitlesi için nasıl değer yaratabileceğini bildirmektedir (Gisladottir, 2016: 18).

Kişisel marka olmuş bireyler, olumlu algılarla birlikte, insanların gözlerinde bir fark yaratan ve kişi özellikleri ne olursa olsun kendilerini benzerlerinden ayıran, toplumun algılarını etkileyen ve yönetebilen, geriye bakıldığında da iyi bir izlenim bırakan bireylerdir. Kişisel marka; yaşamdaki duruşu ve meslektaşlarına kattığı değer ile işine kattığı haysiyet ile dış dünyaya yansıttı̆̆ı mesajına dayanan kişisel kimlik olarak tanımlanmaktadır (Eker, 2007: 8).

Kişisel marka oluşturma sürecinde kişilik özelliklerindeki benzersizliğin tespit edilmesi ve bunun kitleye pazarlanması, kişisel bir marka yaratmada son derece önemlidir. Her ne kadar kişisel markanın, bireyin iddia ettiği şeyi sunması gerektiği savunulsa da, dijital ve çevrimiçi platformlar bir şekilde çevrimdışı markayla kıyaslanırken kişisel marka ile ilgili bir karışıklık ve şüphe kaynağıdır. Çeşitli kişisel marka türlerinin aynı anda birden fazla alıcıya aktarılabilmesi mümkündür. Kişisel markalaşma çeşitli yayınlarıyla 90 'lı yıllarda popülerlik kazanmıştır (Shepherd, 2005: 2).

Güçlü bir kişisel marka, bireyin hem iç (içinde çalıştıkları organizasyon) hem de dış (yerel, bölgesel vb.) iş piyasasında rekabet gücünü arttırmaktadır. İç iş piyasasında rekabet gücünün artması, çalışanlara terfi için daha iyi beklentiler, daha kararlı ve yönetici özerklik imkânı getirir. Aynı zamanda kişinin otoritesini arttırır, bu nedenle bir kişinin yönetim pozisyonlarını tutması ve başkalarını yönetmesi daha kolaydır. Kararların ve eylemlerin şeffaflı̆̆ı, netliği ve tutarlılığı temelinde kendine güven verir. Başka bir deyişle, güçlü kişisel marka, profesyonel ve kişisel doğanın tüm faydalarıyla profesyonel kariyer yapma sürecini kolaylaştırır (Figurska, 2016: 36).

Kişisel bir marka geliştiren bireyler çok sayıda yeni firsat elde etmektedir. Yeni kariyer fırsatlarını keşfetmek, çalışmaları için çeşitli kitlelere ulaşmak veya başkalarının hayatlarını zenginleştirmek, kişisel markanın önemini vurgulayan ve birkaç avantaj sağlayan örneklerdendir. İşverenler genellikle işe alma süreçlerinde onlara yardımcı olmak için sosyal ağ sitelerini kullanmaktadırlar. Sosyal a $\breve{g}$ siteleri, işverenler tarafindan başvuru sahipleri aracılığıyla sağlanan bilgilerin doğrulanmasına yardımcı olmak için kullanılmaktadır.. $\mathrm{Bu}$ nedenle, kendilerini doğru bir şekilde markalamayan bireyler geride kalma riski taşırlar ve en iyi kariyer firsatlarını kaçırabilmektedirler. Kişisel markalaşmaya dâhil olmak çok avantajlı bir çaba olmakla birlikte, kişisel markalaşmaya aktif olarak katılmayı ihmal etmek de bireyin çabaları üzerinde bir etki yapma potansiyeline sahiptir (Wait, 2018: 5).

Kişisel marka, pazarlama bakış açısıyla bakıldığında günlük hayattaki diğer insanlar gibi, müşterilere de gösterilen davranışın aynısını içermektedir. Kişisel marka esnektir ve farklı rollere bürünebileceğinden davranış değişikliklerini de kapsamaktadır. Kişisel marka çalışmaları, kişiye hangi niteliklerin bireysel olarak en belirgin olduğunu söylemektedir. Buradan hareketle, kişisel bir marka olmak kişinin davranışını olumlu yönde etkileyebilmekte, kişiye gönül rahatlığı sağlamakta ve kişinin daha farkına varmadığ ihtiyaçları ortaya koymaktadır (Naghiyev, 2019: 65).

Kişisel marka; insanlara benzerlikler ortamında öne çıkma yeteneği verir. Uzun ömürlü ve itibar sahibi bir kişisel marka, güven ve kalite kavramlarını zihinlerde canlandırmalıdır. İnsanların zihninde bu kavramları anımsatan kişi, toplumda uzun vadeli bir itibara kazanacak ve kişisel bir marka olarak kabullenecektir (Yaman, 2012: 186). 


\subsection{Kișisel Markalașma Unsurları}

Kişisel marka, bir kişinin becerilerinin, tutkularının ve değerlerinin ifadesidir. Marka, bir ürünün gücünün ve pazardaki koşullarının çözümlendiği bir süreçtir. Bu noktada, kişisel bir marka yaratmanın altı önemli unsuru bulunmaktadır (Çayıroğlu, 2010: 51). Bu unsurlar; kişisel değerler, yönetim becerileri, iletişim, kişisel farkındalık, kişilik, kişisel imaj, hedefler ve fiziksel yapıdır.

Kişisel Değerler: Kişisel marka yaratma sürecini başlatan her bireyin gündeminde olması gereken önemli unsurlardan biri, bireyin kendi değerleridir. Marka olgunlaştıkça, bu değerlere bağlı kalarak, marka stratejileri oluşturmak bireyi farklı ve sürekli hale getirecektir (Eker, 2007: 70).Bireyin güçlü yönlerini iyi tanıması ve isteklerinin izinde yürümesi bireye ilham verecektir. Bu sebeple, bireyler eksikliklerini geliştirmeye başlamadan önce temel değerlerini detaylı bir şekilde incelemelidir (Moralıoğlu, 2015: 214).

Yönetim Becerileri: Gelişmiş yönetim becerilerine sahip bireyler, birçok konuda kendilerini iyi yetiştirmiş, hitap etme, inandırma, yöneltme ve yönetme konusunda epey yetenekli bireylerdir. Dolayısıyla kişisel markaların en açık niteliklerinden biri lider olma yetenekleridir. Lider birey, şartlara bağlı olarak, üyesi olduğu grubun üstünde veya ekibin en alt seviyesinde olabilir (Naghiyev, 2019: 67).

İletişim: İletişim, basitçe bilgiyi bir yerden, kişiden veya gruptan diğerine aktarma eylemidir. Başarılı bir kişisel marka olmanın yollarından birisi doğru anlaşılmaktan geçmektedir. Sadece kişisel bir marka olmak değil, aynı zamanda bir kişinin her şeyde başarılı olması önemlidir. Bu nedenle, marka olmak isteyen bireyin yazılı, sözlü ve sözsüz iletişim becerilerini geliştirmesi beklemektedir (Ker Dinçer, 2001: 67).

Kişisel Farkındalık: Kendi kendini çözme, kendinin tam anlamıyla farkına varması, bir insanı başarı yolunda daha ileriye taşıyabilmektedir. Buna ek olarak birey, sahip olduğu özellik ve yeteneklerinin farkında olduğu sürece karşılaşacağı pek çok problemin üstesinden gelebilir (Demir, 2019: 25).

Kişilik: Kişi hayata baktığında, zihninde olmak istediği kişi ile aslında olduğu kişi arasında büyük farklılıklar olabilir. Bu farkı anlamak için, birey kendi içerisinde; kararlı, hırslı, sadık, samimi, cesur, gerçekçi, çalışkan, dürüst, yaratıcı, duygusal, düşünceli, sakin, enerjik, güçlü, yararlı gibi çeşitli değerlendirmeler yapması gerekmektedir. Kişiyi tamamladığı zannedilen ve kişiliği belirlemek amacıyla bazı üstünlüklerin belirlendiği bir liste oluşturulmalıdır (Özharputlu, 2019: 58).

Kişisel İmaj: Kişisel imaj, hem bireyin hem de bir başkasının zihninde oluşmuş algılar ve görüntüler olarak ifade edilir. Bu görüntü dışarıdaki kişiyi temsil eder, aynı zamanda diğer insanların da kafalarına yerleşmiştir. Bu temsili görüntü, bireyin diğer insanlarla aynı yerde olmaması durumunda, birey hakkındaki düşünceleri zihinlerde harici imaj aracılığıyla oluşmaktadır. Kişisel imaj sıradan bir dekorasyon aracı değil, tam olarak bir işi yapmak ve başarılı bir meslek yaratmanın önemli bir adımıdır. Bireyin kendisini tüm iletişim araçlarını kullanarak mümkün olduğunca başarılı ve etkileyici bir şekilde ifade etmesidir. Kişisel imajı insanların zihninde şekillendirmenin ilk adımı, kişiyi nasıl algıladıklarını anlamaktır (Alkevli, 2015: 158).

Hedefler: Hedef kavramı genel tanım olarak ele alındığında iş, maksat ve ulaşılacak yer, erişilecek son radde gibi çeşitli ifadeleri olduğu görülmektedir. Bu noktada vurgulanmak istenen kişisel hedef kavramı, bireyin ileride kendini görmek istediği yer olarak da tanımlanabilir (Letang, 2019: 18). 
Fiziksel Yapı: Fiziksel yapı, kișisel bir marka oluştururken göz önünde bulundurulmas1 gereken bir başka unsurdur. Bireyin dışarıdan görüntüsü fiziksel yapısını oluşturur. Bireyin iradesine göre şekillendirebileceği fiziksel yapı, genellikle kalıtımla birlikte gelen bazı doğal özellikler olarak kabul edilmektedir. Kişinin konumu ve yaratmaya çabaladığı kişisel marka imajı ile uyum sağlaması ve giydiği kıyafet ve aksesuarlarla uyumlu olması gerekir. Örnek olarak, fazla kilolu bir kişinin kilo vermek için bir diyetisyene gitmek istemesi ve gittiği diyetisyenin aşırı kilolu olduğunu gördüğünde, alacağı hizmet hakkındaki fikri doğrudan olumsuz olarak etkilenecektir (Bişkin ve Kaya, 2011: 566).

\section{Yöntem}

Turist rehberleri, ülkeyi yerel ve uluslararası gruplara iyi tanıtabilen, gruplara yolculuklarında yardımcı olabilen, gerekli detayları derinlemesine bilen ve Kültür ve Turizm Bakanlığ 1 tarafindan verilen yetki belgesini verilen kişilerdir. Turist rehberleri, turistlerin seyahat deneyimlerinden memnun olmalarının sağlanmasında, bölgenin olumlu bir resmini oluşturup güçlendirmede önemli bir rol oynamaktadır. Literatür taraması sonucunda turizm rehberliği konusunda çok sayıda çalışma yapıldığ 1 görülmektedir.

$\mathrm{Bu}$ çalışma, Türkiye'de tanınan turist rehberlerinin markalaşma yolundaki stratejilerini incelemek ve rehber adaylarına bu doğrultuda tavsiyeler vermek için yapılmıştır. Araştırmada rehberlerin marka yaklaşımlarını ve stratejilerini ortaya koymak üzere 10 sorudan oluşan bir görüşme gerçekleştirilmiştir. Literatür taraması sonucunda kişisel marka çalışmalarının genellikle bir veya birkaç kişi ile yapıldığ görülmektedir (Canbay, 2014; Naghiyev, 2019). Dolayısıyla bu çalışmada da markalaşan turist rehberleri ile görüşmeler yapılmıştır. Hem sektörde yer alan uzman turist rehberleri hem de akademisyenler tarafindan alınan görüşler doğrultusunda bu isimler belirlenmiştir. Bunlara ek olarak, çalışamaya dâhil olan rehberlerin medyada çeşitli yayınlara katılması (TV ve radyo programları), yaptıkları kitap, dergi vb. akademik yayınlar ve sosyal medyada belirli bir sayıya ulaşan rehberler olması da araştırma için önemlidir.

$\mathrm{Bu}$ araştırmada nitel araştırma yöntemi kullanılmıştır. Nitel araştırma, bir olayı, durumu veya konuyu katılımcıların bakış açısı ile derinlemesine anlamlandıran, detaylandıran ve bütüncül olarak incelenmesine imkân tanıyan bir araştırma yöntemidir. $\mathrm{Bu}$ yöntem içerisinde kullanılan fenomolojik araştırma türünde ise araştırılan konuyu veya olguyu katılımcıların daha önce deneyimlemiş olması gerekmektedir (Creswell, 2014:30). Nitel veri karmaşık durumları ortaya koymaya yönelik güçlü bir potansiyelle birlikte zengin ve bütüncül bir içerik sunmaktadır. Bu tür veriler, gerçeğe ilişkin ilk elden ve etkili betimlemeler sağlamaktadır. Yapılan bu çalışmada markalaşan turist rehberlerinin stratejilerinin incelenmesi sebebiyle çalışmaya nitel yöntem uygun görülmüştür. Nitel araştırmada, sayısal olmayan verilerin toplanması ve hedeflenen kişi veya yerlerin araştırılması yoluyla sosyal yaşamı anlamaya yardımcı olan bu verilerden anlamı yorumlamaya çalışan bir tür sosyal bilim araştırmasıdır. Veriler, araştırmacı tarafından doğal ortamlarda veya görüşmelerde, kamuya açık veya kişisel; kâğıt tabanlı veya elektronik belgelerde yapılan gözlem veya röportajlar, ses veya video kayıtları sırasında araştırmacı tarafindan yazılan alan notları biçiminde olabilmektedir. Nitel araştırmanın amacı, bireylerin, grupların ve kültürlerin sosyal gerçekliğini, katılımcılarının hissettiği veya yaşadığı kadar olabildiğince anlamaktır. Böylece insanlar ve gruplar doğal ortamlarında incelenir (Ryan vd., 2009: 309).

Veri toplama aşamasında ise görüşme tekniğinden yararlanılarak ilgili rehberler ile görüşmeler gerçekleştirilmiştir. Görüşmeler yarı yapılandırılmış ve yapılandırılmış olarak 3 profesyonel turist rehberi ile yapılmıştır. Özge Ersu ile yüz yüze yapılan yarı yapılandırılmış görüşmede, görüşme formundaki 8,9 ve 10. sorular ek olarak sorulmuştur. Sedat Bornovalı 
ve Nükhet Everi ile yapılan görüşmeler Covid-19 tedbirleri kapsamında internet üzerinden yapılandırılmış olarak gerçekleşmiştir ve görüşme formundaki tüm sorular sorulmuştur.

$\mathrm{Bu}$ araştırmada turist rehberliğinde kişisel marka olarak bilinen kişiler ile görüşmeler yapılmıştır. Bu rehberler belirlenirken öncelikle hem sektörde yer alan uzman turist rehberlerinden hem de akademisyenler tarafından alınan görüşler doğrultusunda ilerlenmiştir. Buna ek olarak, çalışmaya katılan rehberlerin medyadaki çeşitli yayınlarda aktif olmaları (televizyon ve radyo programları gibi), yazdıkları kitap, dergi makalesi vb. yayınlar ve günümüzde son derece önemli bir yer tutan sosyal medyada belirli bir kitleye ulaşan kişiler olmaları da görüşmeler için önem arz etmektedir. Araştırma Mart - Mayıs 2020 tarihleri arasında yapılmıştır.

Çalışmada turist rehberlerine on soru yönetilmiştir. Sorular kişisel marka literatüründen elde edilen veriler ile turist rehberlerine uyarlanmıştır (Hepekiz ve Gökalier, 2019; Wait, 2018; Alkevli, 2015; Işıklı, 2019; Naghiyev, 2019; Canbay, 2014). Bu sorular aşağıdaki gibidir:

1- Marka rehber tanımınız nedir? "Marka rehber" konusuna nasıl yaklaşıyorsunuz?

2- Turist rehberliğinde markalaşmanın gerekli olduğunu düşünüyor musunuz? Rehberlere ve rehber adaylarına markalaşma açısından tavsiyeleriniz nelerdir?

3- Markalaşmış turist rehberleri, markalaşma süreçlerinde nasıl bir pazarlama stratejisi izlemektedir?

4- Turist rehberliğinde kişisel marka yaratma sürecinde önemli olan faktörler nelerdir? Etkili bir kişisel marka stratejisi turist rehberliğinde nasıl yaratılır?

5- Marka rehber olmanın yurtiçi ve yurtdışı turlarda size getirdiği avantaj veya dezavantajları var midir?

6- Markalaşmış turist rehberlerinin tur fiyatlarında herhangi bir değişiklik gözleniyor $\mathrm{mu}$ ?

7- Sosyal medya turist rehberleri açısından markalaşma aracı niteliği taşımakta mıdır ve sosyal medyada rehberlik ile ilgili içerikler üretiyor musunuz? Sosyal medya alanında destek aliyor musunuz?

8- Kişisel markalı turist rehberi olarak miras alanlarına(ören yerleri) nasıl yaklaşıyorsunuz? Turistlerden geri bildirim alıyor musunuz? Geri bildirimlerden sonra eylemlerinizi değiştirir misiniz (ayrıntılı bilgi, ses seviyesi, yürüme hızı vb.)?

9- Anlatılarınızda (ifade biçimi) turistik yerlerde yerel ve uluslararası turistler arasında herhangi bir fark var mı?

10- Turlarına nasıl hazırlanıyorsunuz? Buna ek olarak rehber adaylarına önereceğiniz en önemli yabanc1 diller hangisidir?

\section{Bulgular}

Bulgular değerlendirilirken, görüşme yapılan üç rehberin her bir soruya verdiği cevaplar değerlendirilmiştir.

Tablo 1. Katılımcıların demografik özellikleri

\begin{tabular}{|l|l|l|l|l|}
\hline Katılımcılar & Yaş & $\begin{array}{l}\text { Tecrübe } \\
(\text { Yıl })\end{array}$ & Eğitim Durumu & Cinsiyet \\
\hline I. Katılımcı & 55 & $30+$ & $\begin{array}{l}\text { Lisans ve } \\
\text { Önlisans }\end{array}$ & Erkek \\
\hline II. Katılımcı & 50 & $30+$ & Doktora & Erkek \\
\hline III. Katılımcı & 60 & $30+$ & Lisans & Kadın \\
\hline
\end{tabular}


Tablo 1'de görüldüğü gibi veri elde edilen 3 katılımcıya ilişkin demografik özellikler incelendiğinde, katılımcılardan 1 kişinin kadın, 2 kişinin erkek olduğu görülmektedir. Katılımcıların yaş aralığı 50-60'tır. Her bir katılımcının rehberlik mesleğindeki deneyimlerinin 30 yıl ve üzerinde olduğu saptanmıştır. Katılımcılar en az lisans eğitimini tamamlamış olup, eğitim seviyesi en fazla doktora eğitimine kadar yükselmektedir.

Şekil 1. Araştırma verilerinden elde edilen boyutlar ve temalar

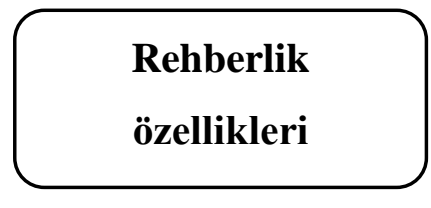

- Bilgi düzeyi

- Anlatım biçimi

- Sunum yeteneği

- Organizasyon becerisi

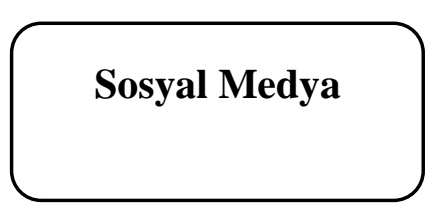

- Görünürlük

- Pazarlama araci

- Hedef kitle

- Konumlandirma

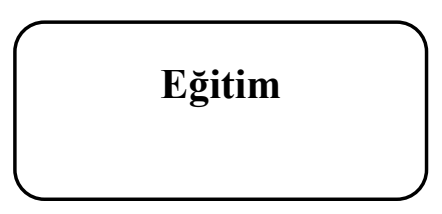

- Örgün eğitim

- Sahne sanatları eğitimi

- Yabanci dil eğitimi

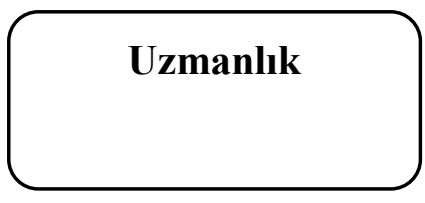

- Destinasyon uzmanlığ

- Ören yeri uzmanlığ1

- Yap1 (anıt) uzmanlığ1

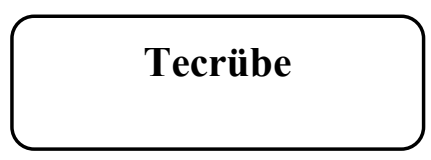

- Turizm tecrübesi

- Rehberlik tecrübesi

\section{Yabancı Dil}

\section{Aktiviteler}

Rehberlik ve marka ile ilgili ifadeler eğitim, yabancı dil, tecrübe, uzmanlık, rehberlik özellikleri, sosyal medya ve aktiviteler olmak üzere toplam 7 boyuta toplanmış ve Tablo 2.'de gösterildiği gibi temalarıyla birlikte aktarılmıştır. Boyutlar literatürden elde edilen bilgilerden yola çıkarak, temalar da görüşmelerden elde edilen veriler 1şı̆̆ında oluşturulmuştur. Rehber özellikleri boyutu, bilgi düzeyi, anlatım biçimi, yorumlama becerisi, sunum yeteneği ve organizasyon becerisi olmak üzere 4 temadan oluşmaktadır. Sosyal medya boyutu, görünürlük, pazarlama aracı, hedef kitle seçimi ve konumlandırma olmak üzere 4 temadan oluşmaktadır. Eğitim boyutu, örgün eğitim, yabancı dil eğitimi ve sahne 
sanatları eğitimi olmak üzere 3 temadan oluşmaktadır. Uzmanlık boyutu, destinasyon uzmanlığı, ören yeri uzmanlığ 1 ve yapı (anıt) uzmanlığ 1 olmak üzere 3 temadan oluşmaktadır. Tecrübe boyutu, turizm tecrübesi ve rehberlik olmak üzere 2 temadan oluşmaktadır. Yabancı dil boyutu ve aktiviteler boyutlarında ise hiçbir tema yer almamaktadır. Boyutlar en fazla tema sayısından en az tema sayısına doğru sıralanmıştır. Toplamda 7 boyut ve 16 tema bulunmaktadır. Bulguların analiz edilmesine yönelik oluşturulan temalar ve alt kategoriler aşağıdaki gibidir. $\mathrm{Bu}$ temalar katılımcıların anlatılarından elde edilerek doğrudan alıntılarla desteklenmiştir.

Tablo 2. Rehber özellikleri boyutuna ilişkin temalar ve ifadeler

\begin{tabular}{|c|c|}
\hline Bilgi düzeyi & $\begin{array}{ll}\text { - } & \text { Bilgi içeren katalog/broşür hazırlanması } \\
\text { - } & \text { Temel düzeyde rehberlik bilgisine sahip } \\
\text { olunması } & \\
\text { - } & \begin{array}{l}\text { Bilgilerin aktarımında boyutlar } \\
\text { kullanılması }\end{array} \\
\end{array}$ \\
\hline Anlatım biçimi & $\begin{array}{ll}\text { - } & \text { Yerli ve yabancı gruplarda farklı anlatım } \\
\text { - sekli benimsenmesi } \\
\text { - } & \text { Etkili bir hitap kullanılması } \\
\text { - } & \text { Ses kullanımında ustalaşılması } \\
\text { - } & \text { Yorumlama becerisinin geliştirilmesi } \\
\end{array}$ \\
\hline Sunum yeteneği & $\begin{array}{l}\text { - } \begin{array}{l}\text { Rehberin kendisini etkili biçimde } \\
\text { tanıtması }\end{array} \\
\text { - } \begin{array}{l}\text { Kendine has bir pazarlama yöntemi } \\
\text { oluşturulması }\end{array}\end{array}$ \\
\hline Organizasyon becerisi & $\begin{array}{l}\text { - } \text { Tur öncesi hazırlık yapılması } \\
\text { - Rotaların ve güzergâhların dosya } \\
\text { biçiminde oluşturulması } \\
\text { - Her duruma uygun bir senaryonun } \\
\text { geliştirilmesi }\end{array}$ \\
\hline
\end{tabular}

Katılımcılardan Özge Ersu turlarında hazırlanırken her şeyden önce konuyu bildiğini vurgulamaktadır. Bu bilgisinin yanı sıra tur sabahı erken kalkıp çalışılması gerektiğine dikkat çekmektedir. Hatta turdan önce ziyaretçilerini destinasyon hakkında bilgilendirdiği görülmektedir. Öte yandan Sedat Bornovalı turlarına hazırlanırken özel bir hazırlık yapmadığını, yalnızca güzergâhlar üzerinde çalıştığını belirtmektedir. Buna ek olarak, rehberin kendisini bir sporcu gibi hazırlaması gerektiğini, uyku düzenine ve beslenmesine de önem vermesi gerektiğini dile getirmektedir. Nükhet Everi ise kendisinin bir çalışma planı olduğunu ve tura başlamadan önce gerekli araştırmaları yaptığını aktarmaktadır. Marka turist rehberlerinin yerli ve yabancı gruplarda anlatım biçimlerinde kesinlikle bir fark olduğu gözlenmektedir. Üç katılımcı da aynı görüşü beyan etmekte ve bu farkın kişiye profesyonellik katacağını da vurgulamaktadır. Nitekim rehberlik literatürü de bu görüşleri desteklemektedir. Hatta Özge Ersu anlatım biçiminin demografik, cinsiyet, medeni ve öğrenim durumlarının da göz önüne alınarak aktarılmasının önemli olduğuna dikkat çekmektedir.

Tablo 3. Sosyal medya boyutuna ilişkin temalar ve ifadeler

\begin{tabular}{|l|l|l|}
\hline Görünürlük & $\bullet$ & Toplum tarafından bilinir hale gelinmesi \\
& & Sosyal medya platformlarının aktif \\
& kullanılması & \\
\hline Pazarlama aracı & $\bullet$ & Düzenli paylaşım yapılması \\
& $\bullet$ & Rehberlik içeriklerinin \\
\end{tabular}




\begin{tabular}{|c|c|}
\hline & kullanılmas1 \\
\hline Hedef kitle & $\begin{array}{ll} & \text { Net ve tutarlı biçimde seçim yapılması } \\
\text { - } & \text { Güven ve duygusal bağlantı kurulması } \\
\text { - } & \text { İhtiyaçların giderilmesi }\end{array}$ \\
\hline Konumlandırma & $\begin{array}{ll}\text { - } & \text { Zihinlerde kalıcıllğın sağlanması } \\
\text { - } & \text { Tüketici zihnindeki algıların } \\
\text { sekillendirilmesi }\end{array}$ \\
\hline
\end{tabular}

Günümüzde sosyal medyanın kitleler üzerindeki etkisi oldukça fazladır. Her geçen gün artan kullanıcı sayısı ile sosyal medya önemli pazarlama araçlarındandır. Bu sebeple markalaşma açısından önemli bir yere sahiptir. Bu bağlamda çalışmaya katılan üç turist rehberine sosyal medyanın markalaşma aracı olarak nitelik taşıyıp taşımadığını, sosyal medya platformlarında rehberlik ile ilgili içerik üretip üretmedikleri ve sosyal medya konusunda destek alıp almadıkları sorulmuştur. Katılımcıların üçü de sosyal medyanın markalaşma aracı niteliğini taşıdığını ve markanın daha da tanınır bir hale getirdiğini savunmaktadırlar. Buna ek olarak katılımcılar sosyal medyada rehberlik içeriği ürettiklerini dile getirmektedirler. Özge Ersu, sosyal medyanın yanı sıra marka olacak rehberin kesinlikle kendisine ait bir internet sayfası olmasını gerektiğini özellikle vurgulamaktadır. Hem kişisel sosyal medya platformlarında hem de kişisel internet sayfasında marka rehberin deneyimlerini yazması gerektiğini de eklemektedir. Ancak Sedat Bornovalı kendisine ait bir internet sayfası olmadığını da belirtmektedir. $\mathrm{Bu}$ yönüyle de Özge Ersu'dan farklı bir bakış açısına sahip olduğu görülmektedir. Sosyal medyada destek konusunda ise Nükhet Everi bir danışman ile çalışmanın işi daha ciddi ve daha verimli bir hale getireceğini savunmaktadır. Ancak Özge Ersu farklı bir görüş belirterek herhangi bir destek almadığını, bütün sosyal medya platformlarını kendisinin yönettiğini belirtmektedir.

Tablo 4. Eğitim boyutuna ilişkin temalar ve ifadeler

\begin{tabular}{|c|c|}
\hline Örgün eğitim & $\begin{array}{ll}\text { - Önlisans, lisans veya lisansüstü eğitimin } \\
\text { alınması } \\
\text { - Mesleki eğitimin öneminin farkına } \\
\text { varılması } \\
\text { - Eğitimin sürekli olarak devam etmesi }\end{array}$ \\
\hline Sahne sanatları eğitimi & $\begin{array}{lllll}\text { - } & \begin{array}{l}\text { Ses kullanımında } \\
\text { gelinmesi }\end{array}\end{array}$ iyi bir seviyeye \\
\hline Yabancı dil eğitimi & $\begin{array}{l}\text { - Akıcı ve etkili yabanc1 dil eğitiminin } \\
\text { alınması } \\
\text { - En az bir yabancı dilin iyi bilinmesi } \\
\text { - İspanyolcanı rehberler açısından } \\
\text { öneminin artması }\end{array}$ \\
\hline
\end{tabular}

Marka rehber olma yolunda eğitim boyutu da oldukça önemlidir. Çalışmada yer alan rehberlerin eğitimleri ileri düzeydedir. Nükhet Everi Viyana'da eğitim alması dolayısıyla hem arkeoloji hem de Alman dili açısından oldukça yetkindir. Sedat Bornovalı İspanyolca, İngilizce, İtalyanca ve Fransızcayı akıcı konuşabilmektedir ve sanat tarihi alanında almış olduğu doktora derecesi de kendisini üst bir seviyeye taşımaktadır. Papanın Türkiye'yi ziyareti sırasında rehberlik görevini üstlenmiş ve İtalyancadan çeviriler yapmıştır. Buna ek olarak, Özge Ersu'nun da Boğaziçi Üniversitesinde İngilizce eğitim aldığı ve akıcı olarak Fransızca konuştuğu da bilinmektedir. Alınan eğitim sayesinde marka rehber olmak isteyen adaylar kendilerini bir veya birkaç alanda uzman konumuna taşıyabilir. Böylece pazarda kendilerine daha kolay yer edinebilirler. 
Tablo 5. Uzmanlık boyutuna ilişkin temalar ve ifadeler

\begin{tabular}{|c|c|}
\hline Destinasyon uzmanlığı & 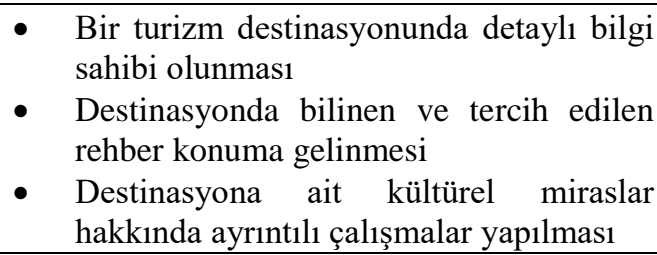 \\
\hline Ören yeri uzmanlığı & $\begin{array}{l}\text { Belirli bir ören yerinde sürekli olarak } \\
\text { rehberliğin sürdürülmesi } \\
\text { Ören yerinde aranan bir rehber } \\
\text { konumuna gelinmesi } \\
\text { - Ören yeri hakkında çeşitli yayınlar } \\
\text { yapılması }\end{array}$ \\
\hline Yapı (anıt) uzmanlığı & $\begin{array}{l}\text { Yap1 (anıt) üzerinde tecrübe sahibi } \\
\text { olunması } \\
\text { - Yorumla becerisinin gelişmiş seviyede } \\
\text { olması } \\
\text { - Rehber olarak anıt ile özdeşleşmiş bir } \\
\text { konuma gelinmesi }\end{array}$ \\
\hline
\end{tabular}

Bir diğer boyut olan uzmanlık boyutu da kişisel marka haline gelmek isteyen her rehberin dikkat etmesi gereken bir noktadır. Çalışmaya dâhil olan rehberlerin belli alanlarda uzman oldukları bilinmektedir. Sedat Bornovalı'nın sanat tarihi ve Ayasofya konularındaki doktora çalışmaları, Nükhet Everi'nin özellikle Mardin bölgesindeki detaylı yayınları ve yayınladığı Mardin Güneş Ülkesi adlı kitabı, Özge Ersu'nun da Afrika, Yeni Zelanda ve İstanbul'un çeşitli bölgelerindeki rehberlik aktiviteleri uzmanlık alanlarına örnek olarak verilmektedir. Uzmanlık boyutu pek çok alanda rehbere yol gösterebilmektedir. Rehber önceden uzmanlaşmak istediği destinasyonu veya alanı belirleyip bu yolda ilerlediği takdirde marka değerine güç katacaktır.

Tablo 6. Tecrübe boyutuna ilişkin temalar ve ifadeler

\begin{tabular}{|l|r|l|}
\hline Turizm tecrübesi & $\bullet$ & Sürekli olarak sektörle iç içe olunması \\
\hline Rehberlik tecrübesi & $\bullet$ & Mesleğin uzun y1llar aktif olarak \\
& & sürdürülmesi \\
& $\bullet$ & Turlarda daha etkili performans \\
& & sergilenmesi \\
& $\bullet$ & Turun bütün detaylarının bilinmesi \\
\hline
\end{tabular}

Marka rehber olabilmek ciddi sabır gerektiren uzun bir süreçtir. Bir rehberin marka haline gelebilmesi için uzun yıllar sektör paydaşları ile iç içe çalışması ve talep edilen bir rehber konumuna gelmesi gerekmektedir. Çalışmaya katılan rehberler incelendiğinde her birinin uzun yıllardır sektörde aktif olarak bulunduğu görülmektedir. Bu nedenle rehberlik ve markanın ortak bir diğer ortak bileşeni de tecrübe boyutudur. Kişisel marka haline uzun süren zorlu ve sabır gerektiren bir yoldur. Ortalama 30 yıldır rehberlik yapan katılımciların da görüşleri, marka haline gelmenin bir anda mümkün olmayacağını, bu yolda yürürken birçok engelin bulunduğunu ve çok sıkı çalışmak gerektiğini de vurgulamaktadır. Tecrübe boyutu, marka bir rehber haline gelebilmek için önemli ölçütlerdendir.

\section{Değerlendirme ve Sonuç}


Turizm rehberliği çok boyutlu bir meslek olarak değerlendirildiğinde bu mesleğin içerisinde hali hazırda var olan marka olgusunu rehberlerin gözünden değerlendirmek amacıyla bu araştırma konusu seçilmiş ve gündeme uygun olarak ismini ve mesleğini birçok topluluğa duyurmuş, marka rehber niteliği taşıdığ1 düşünülen üç turist rehberi ile görüşmeler yapılmıştır.

Kişisel marka kavramı, rekabetin giderek arttığı günümüz dünyasında yalnızca tanınmış bireylerin değil, aynı zamanda özel hayatında ve iş hayatında başarılı olmak isteyen herkesin önem vermesi gerektiği bir kavramdır. Kişisel markanın oluşmasında birçok etken bulunmaktadır. Bu etkenlere imaj, hedef kitle, verdiği mesaj ve sahip olduğu kişisel değerler örnek gösterilebilir. Fakat kişisel marka olabilmek için bu etkenler tek başına yeterli değildir. Marka haline gelmek isteyen birey, öncelikle fikirleri yönetebilme ve toplumlar üzerinde etki bırakabilme gücüne sahip olmalıdır.

Destinasyon ve kültür tanıtıcılı̆̆ görevini arz eden bu meslekte rekabet olgusu diğer mesleklerde olduğu gibi belirgindir. Marka tek bir bileşenden meydana gelmediği gibi birçok etkeni bünyesinde bulunduran geniş bir kavramdır. Rehberlik mesleğinde marka olarak tanınmak ve anılmak uzun bir sürece yayılım gösterebildiği gibi bireyin varoluşsal bir takım özellikleriyle de kısa süre içerisinde gerçekleşebilmektedir. $\mathrm{Bu}$ özellikler çevreyle iletişimden, lisan çeşitliliği ve kişisel bilgi donanımına kadar uzanabilmektedir.

Öncelikle kişisel bir marka oluşturmak isteyen rehberlerin hangi değerlere, kim olduklarına ve hangi inançlara sahip olduklarını bilmeleri gerekmektedir. Marka kişinin ilettiği mesaj ve sahip oldukları bu temel değerler tutarlı olmalıdır ve desteklenmelidir. Güçlü bir marka inşa etmek ve bu marka değerini sürdürmek için hedef kitlelere gönderilen mesajın tutarlı ve net olması gerekmektedir. Ayrıca marka rehber birçok platformda aktif bir biçimde rol aldığı için görüntüsüne özen göstermelidir ve sık sık değiştirmemelidir. Kitleler üzerinde görünebilir kalmak marka değerini artıracaktır. Sürekli görünür olan bir turist rehberi kendisini rakiplerinden kolayca farklılaştırmaktadır. Bu farklılaşma sayesinde aşırı doymuş bir turizm sektöründe bile avantaj sağlayabilmektedir. Ayrıca yabancı dile hâkim olmak da önemli bir kriterdir. Üç rehberden elde edilen veriye göre İngilizce dışında bir yabancı dile hâkim olmak bu konuda yarar sağlayacaktır

Günümüz popülaritesinde sosyal medyanın gücü yadsınamaz bir gerçektir. Pek çok iş yeri işlevini bu tür mecralar üzerinden gerçekleştirmektedir. Günden güne güncelleşen teknolojik ilerleme ve katlanarak artan bilgi akışı, birçok hizmete bu platformlarda boy gösterme imkânı sağlamıştır. Sosyal medya turizm sektörünün de güçlü bir aracıdır. Özellikle rehberler kendi kişisel sayfalarında yaptıkları paylaşımlarla ulusal ve uluslararası olmak üzere pek çok insana ulaşabilmekte ve bir nevi kendi mesleki pazarlamasını gerçekleștirebilmektedir. Bir pazarlama aracı olarak rehberlerin sosyal medyayı sıklıkla kullanması, günden güne artış gösteren başarılı bir meslek profili çizmesine yardımcı olmaktadir.

Rehberlikte kişisel marka yaratmanın oldukça uzun ve zor bir süreç olduğu gözlenmektedir. Nitekim çalışmaya katılan üç rehberin de cevaplarına bakıldığında rehberlik ve turizm tecrübelerinin çok fazla olduğu bilinmektedir. Bir marka yaratırken zaman alıcı olduğunun ve sonuçlarının anında gelmeyeceğinin farkında olmak gerekmektedir.

Rehberlik literatürü, kişisel marka literatürü ve çalışmaya katılanların görüşleri dâhil olmak üzere, marka yaratmak isteyen bireylerin kesinlikle bir konuda uzmanlaşması gerektiği görülmektedir. Bu uzmanlık hem destinasyonda bir avantaj sağlayacak hem de turlar marka rehber ismiyle hazırlanacaktır. Çalışmada saptanan bir diğer unsur da çalışmaya katılan rehberlerin kişisel marka boyutlarına uymadıklarıdır. Bunun nedeni kişisel marka 
literatürünün henüz çok yeni olması ve rehberlerin de uzun süredir sektörde bulunmaları olarak açıklanabilir. Dolayısıyla bu rehberler kendilerine has yöntemlerle kişisel marka haline gelmişlerdir. Ancak çalışmaya katılan rehberlerin kişisel markalaşma stratejilerinden ola yedi aşamada marka oluşturma ve etkili markalaşma kriterlerden çeşitli maddeleriyle uyum sağladıkları görülmektedir. Bu maddeler süreklilik, görünürlük, uzmanlık ve liderlik olarak sıralanabilir.

Çalışma kapsamında rehberlikte markalaşmanın uygun olduğu saptanmıştır. Literatür verileri ve çalışmaya katılan rehberlerden elde edilen verilerin ışığında rehberlikte markalaşmak oldukça yarar ve birbiri ile uyuşmaktadır. Rehberlik ve kişisel marka literatürü liderlik, anlatım becerileri, görünürlük, süreklilik açılarından birbiriyle uyumludur. Ayrıca katılımcıların da bu özellikleri taşıdığı görülmektedir.

Son olarak, rehberlikte marka olmak isteyen kişiler;

- Uzun süren yıllar ve tecrübe gerektirdiğini iyi bilmeli,

- Hedef kitleyi belirlemeli,

- Belirli bir alanda uzmanlaşmal1,

- Lider görüntüsü oluşturmalı,

- Yenilikçi olmalı,

- İmajına ve logosuna (varsa) dikkat etmeli,

- Başarısını devamlı olarak sürdürmelidir. 


\section{Kaynakça}

Ahipaşaoğlu, S. (2006). Turizmde Rehberlik. Ankara: Gazi Kitabevi.

Akbulut, O. (2006). Ege Bölgesindeki Turist Rehberlerinin Mesleki Sorunları ve Çözüm Önerilerine Yönelik Bir Araştırma. Antalya: Akdeniz Üniversitesi, Turizm İşletmeciliği ve Otelcilik Anabilim Dal, Yüksek Lisans Tezi.

Alkevli, A. (2015). Kişisel Marka Yönetimi: Yerel Seçimlerde Seçmenlerin Kişisel Marka Algisı Ille Illgili Adana Illinde Bir Uygulama. Adana: Çukurova Üniversitesi, Sosyal Bilimler Enstitüsü, Yüksek Lisans Tezi.

Angyus, S. (2017). Personal Branding: A Practical Guide for Building a Personal Brand as a Student Using Social Media. Tampere: Tampere University of Applied Sciences, Degree Programme in International Business, Bachelor's Thesis.

Ap, J., \& Wong, K. F. (2001). Case Study on Tour Guiding: Professionalism, Issues and Problems. Tourism Management, 551-563.

Batman, O., Demirtaş, N., \& Yıldırgan, R. (2000). Turizm Rehberliği. Sakarya: Değişim Yayınları.

Bişkin, F., \& Kaya, Y. (2011). İş Hayatında Kişisel Marka. Sosyal Ekonomik Araştırmalar Dergisi, 555-570.

Boyle, A., \& Arnott, A. (2004). What Tour Guide Stories can Tell us about Learning, Education and Training: A Case Study in the Top End of the Northern Territory. Common Ground Publishing, 86-94.

Canbay, B. (2014). Türkiye'de Roman Yazarlarının Markalaşma Süreci: Elif Şafak Örneği. Ankara: Ankara Üniversitesi, Sosyal Bilimler Enstitüsü, Yüksek Lisans Tezi.

Charkas, H., \& Eltun, A. B. (2014). Branding in Social Media: A Qualitative Study of Three Swedish Municipalities. Halmstad: Halmstad University, International Marketing, Master Thesis.

Creswell, J. W. (2014). Research Design: Qualitative, Quantitative and Mixed Methods Approaches. California: Sage Publications.

Çayıroğlu, A. (2010). Markalaşma ve Reklam. İstanbul: Etap Yayınevi.

Çimrin, H. (1995). Turizm ve Turist Rehberliğinin ABC'si. Antalya: Akdeniz Kitabevi.

Çınar, B. (2018). Turizm Rehberliği Bölümü Öğrencilerinde Genel Özyeterlilik Algısl, Mesleki Kaygı ve Mesleği Yapma Niyeti Illişkisi. Mersin: Mersin Üniversitesi, Sosyal Bilimler Enstitüsü, Turizm Rehberliği Anabilim Dalı,Yüksek Lisans Tezi.

Demir, H. (2019). Kişisel Marka ve Liderlik Kavramının Siyasal Pazarlama Üzerindeki Etkisi: 1983-1989 Turgut Özal Dönemi Örneği. Aksaray: Aksaray Üniversitesi, Sosyal Bilimler Enstitüsü, Yüksek Lisans Tezi.

Eker, S. (2007). Provasız Hayatta Kişisel Marka Olabilmek. Ankara: Nobel Akademik Yayınc1lik.

Figurska, I. (2016). Personal Branding as an Element of Employees' Professional Development. Human Resources Management \& Ergonomics , 33-47.

Gisladottir, I. E. (2016). It's a Brand New World: Develop a Strong Personal Brand. Reykjavik: University of Iceland, Bachelor Thesis. 
Güzel, Ö. (2007). Türkiye Imajının Geliştirilmesinde Profesyonel Turist Rehberlerinin Rolü (Alman Turistler Üzerine Bir Araştırma). Balıkesir: Balıkesir Üniversitesi, Sosyal Bilimler Enstitüsü, Yüksek Lisans Tezi.

Hepekiz, İ., \& Gökalier, E. (2019). Sosyal Medya Aracılığıyla Yaratılan Kişisel Markalar ve Benlik Sunumu. Erciyes Illetişim Dergisi, 761-782.

İrigüler, F. (2015). A Research on Tour Guides Use of Emotional Labor and the Relationship between Their Job Satisfaction and Burnout Levels: The Sample of İzmir. İzmir: İzmir Katip Çelebi Üniversitesi, Sosyal Bilimler Enstitüsü, Yüksek Lisans Tezi.

Işıkl1, H. G. (2019). Kişisel Markalaşma Bağlamında Youtube Iç̧eriklerinin Görsel Tasarım Açısından Incelenmesi. Afyonkarahisar: Afyon Kocatepe Üniversitesi, Sosyal Bilimler Enstitüsü, Yüksek Lisans Tezi.

Karakaş, B. (2018). Turist Rehberlerinin Mesleki Sorunları ve Çözüm Önerileri: İstanbul Örneği. Balıkesir: Balıkesir Üniversitesi, Sosyal Bilimler Enstitüsü, Yüksek Lisans Tezi.

Ker Dinçer, M. (2001). Kişisel İmaj. İstanbul: Alfa Yayınları.

Köroğlu, Ö. (2013). Turist Rehberlerinin İş Yaşamındaki Rolleri Üzerine Kavramsal Bir Değerlendirme. Pamukkale Üniversitesi Sosyal Bilimler Enstitüsü Dergisi, 91-112.

Letang, D. (2019). Kişisel Marka Genişletme Stratejisinin Tüketicinin Satın Alma Niyetine Etkileri. İzmir: Ege Üniversitesi, Sosyal Bilimler Enstitüsü, Yüksek Lisans Tezi.

Lukkarinen, A. (2019). Personal Branding with an Online Portfolio in Support of Job Search. Helsinki: Haaga-Helia University of Applied Sciences, İşletme Yönetimi, Lisans Tezi.

Mancini, M. (2001). Conducting Tours: A Practical Guide. Amerika: Delmar.

Maurya, U. K. (2012). What is Brand? A Perpective on Brand Meaning. European Journal Business and Management, 122-134.

Naghiyev, A. (2019). Tanınmış Kişilerin Markalaşmasında Sosyal Medyanın Rolü: Sanatçı Gülşen Örneği. Sakarya: Sakarya Üniversitesi, Sosyal Bilimler Enstitüsü, Yüksek Lisans Tezi.

Özharputlu, H. (2019). Yeni Bir Trend Olarak Kişisel Marka: Türkiye Örneği. Afyonkarahisar: Afyon Kocatepe Üniversitesi, Sosyal Bilimler Enstitüsü, Yüksek Lisans Tezi.

Ryan, F., Coughlan, M., \& Cronin, P. (2009). Interviewing in the Qualitative Research: The One-to-One Interview. International Journal of Therapy and Rehabilitation, 309-314.

Shepherd, I. D. (2005). From Cattle and the Coke to Charlie: Meeting the Challenge of Self Marketing and Personal Branding. Journal of Marketing Management, 1-15.

Tetik, N. (2006). Türkiye'de Profesyonel Turist Rehberliği ve Müștelerin Turist Rehberlerinden Beklentilerinin Analizi (Kuşadası Örneği). Balıkesir: Balıkesir Üniversitesi, Sosyal Bilimler Enstitüsü, Yüksek Lisans Tezi.

Tokay, S. (2015). Profesyonel Turist Rehberlerinin Türkiye Imajını Algılamalarındaki Değişim. Eskişehir: Eskişehir Osmangazi Üniversitesi, Sosyal Bilimler Enstitüsü, Yüksek Lisans Tezi. 
Wait, J. P. (2018). Personal Branding through Social Media. Port Elizabeth: Nelson Mandela Üniversitesi, İşletme ve Ekonomik Bilimler Fakültesi, Yüksek Lisans Tezi.

Yaman, F. (2012). Toplumda Kişisel Marka Olmak: Türkiye'nin Kişisel Markaları. Insan ve Toplum Bilimleri Araştırmaları Dergisi, 182-197.

Zarkada, A. (2012). Concepts and Constructs for Personal Branding: An Exploratory Literature Review Approach. SSRN Electronic Journal, 1-10. Researchgate. adresinden alındı 